\title{
A Novel Cd(II) Isophthalate Complex with Triethanolamine: Crystal Structure, Fluorescence and Antimicrobial Activity
}

\author{
Zuhal Yolcu, ${ }^{1, *}$ Sinem Yurtcan ${ }^{2}$ and Meryem Çıtlakoğlu ${ }^{1}$ \\ ${ }^{1}$ Department of Chemistry, Faculty of Art and Science, Giresun University, Giresun, Turkey \\ ${ }^{2}$ Giresun University Central Research Laboratory Application and Research Center \\ ${ }^{*}$ Corresponding author: E-mail: zuhal.yolcu@giresun.edu.tr
}

Received: $12-22-2020$

\begin{abstract}
A mixed ligand $\mathrm{Cd}(\mathrm{II})$ complex $\left[\mathrm{Cd}(\mathrm{IsoPht})(\mathrm{TEA}) \mathrm{H}_{2} \mathrm{O}\right] \cdot 3 \mathrm{H}_{2} \mathrm{O}$ was synthesized for the first time by using isophthalic acid $\left(\mathrm{H}_{2} \mathrm{IsoPht}\right)$ and tetradentate triethanolamine (TEA) and characterized by X-ray single-crystal diffraction, FT-IR, and thermogravimetric analysis (TGA). This novel complex crystallizes in the triclinic system with $P$ - 1 space group and distorted monocapped trigonal prismatic geometry. The $\mathrm{Cd}(\mathrm{II})$ has seven coordinates with bidentate IsoPht, a TEA in the tetradentate mode, and an aqua ligand. The fluorescence properties of the $\mathrm{Cd}(\mathrm{II})$ complex and TEA ligand were investigated at room temperature. The present $\mathrm{Cd}(\mathrm{II})$ complex was also tested for its antimicrobial activity by in vitro agar diffusion method against some Gram-positive and Gram-negative bacteria and a fungus.
\end{abstract}

Keywords: Isophthalic acid; triethanolamine; Cd(II) complex; X-ray single crystal; antimicrobial activity

\section{Introduction}

Triethanolamine (TEA) is a potential ligand that can interact with metal ions to form supramolecular complexes with different structures, and many coordination compounds containing TEA ligands have been reported for the last two decades. ${ }^{1-6}$ TEA is also used as a $\mathrm{pH}$ regulator in cosmetology, as a corrosion inhibitor in metal-cutting fluids, as a curing agent for epoxy and rubber polymers, in adhesives, antistatic agents, or as a pharmaceutical intermediate. ${ }^{7-9}$ TEA generally acts as the tri- or tetradentate ligand, but some metal complexes with mono- or bidentate TEA coordination modes are also known. ${ }^{10,11}$ Metal complexes containing TEA ligand can be (neutral or cationic) mono-, bi- and polynuclear structures. ${ }^{12,13}$ Some mononuclear mixed ligand complexes were reported for $\mathrm{Ni}(\mathrm{II})$ with TEA and orotic acid, ${ }^{14} \mathrm{Cu}(\mathrm{II})$ with TEA and malonic acid, ${ }^{15} \mathrm{Zn}(\mathrm{II})$ and $\mathrm{Cd}(\mathrm{II})$ with TEA and $p$-nitrobenzoic acid, ${ }^{16} \mathrm{Zn}$ (II) with TEA and aqua ligand, ${ }^{17} \mathrm{Cu}(\mathrm{II})$ with TEA, aqua and $1 \mathrm{H}$-imidazole ligands, ${ }^{18}$ aqua ligand. ${ }^{19}$ Based on the collaborative use of TEA and phthalic acid, mononuclear complexes for $\mathrm{Ni}(\mathrm{II}),{ }^{20} \mathrm{Zn}(\mathrm{II}),{ }^{21} \mathrm{Cd}(\mathrm{II}),{ }^{22}$ and coordination polymer for $\mathrm{Cd}(\mathrm{II})^{23}$ were also reported. Although TEA has no specific physiological effects except for its low antibacterial activity, as an auxiliary ligand TEA may increase the physiological effect of bioactive substances in mixed ligand metal complexes. ${ }^{8,9,24}$ There are preliminary pharmacological studies demonstrating that the transition metal complexes of TEA protect animals from ethanol and carbon monoxide poisoning and have immune-modulating and antiproliferative properties. ${ }^{25-27}$ Also, the mixed ligand zinc complex containing TEA has been reported to have anti-angiogenic and anti-atherogenic effects. ${ }^{28}$

Coordination compounds may combine a metal ion, a biocompatible ligand, and some auxiliary ligands in the same molecule to form mixed-ligand coordination types to achieve the desired properties. ${ }^{29,30}$ Apart from the TEA ligand, isophthalic acid $\left(\mathrm{H}_{2} \mathrm{IsoPht}\right)$ has been selected as a good candidate for this purpose. Dicarboxylic acids have important advantages in design of coordination compounds compared with other organic ligands. Isophthalic acid has two carboxyl groups that can lose one or two protons to form various coordination modes, act as a hydrogen bond acceptor and donor. So it is a versatile and variable ligand that can bind metal ions in different directions. ${ }^{31-38}$ The synthesis of coordination compounds containing $\mathrm{O}$ and/or $\mathrm{N}$-donor ligands are very significant 
and intriguing in the field of pharmacology due to the discovery of their antimicrobial properties. The biological activity of coordination compounds with $\mathrm{O}$-donor ligand isophthalato (IsoPht) has been studied. ${ }^{39-42}$ Antimicrobial activities of $\mathrm{Zn}$-IsoPht complexes were displayed in vitro against some Gram-positive, some Gram-negative bacteria and fungus by Radovanović and co-workers, who showed that the most potent inhibitory effect of [ $\mathrm{Zn}$ (dipya) $($ IsoPht $)]_{\mathrm{n}}\left(\right.$ dipya $=2,2^{\prime}$-dipyridylamine) against all the tested microorganisms. ${ }^{39}$ Devereux and co-workers demonstrated high antibacterial activity of $\mathrm{Mn}$-phenpht/IsoPht complexes against Candida albicans. ${ }^{40}$

Cadmium coordination compounds containing $\mathrm{O}$ and/or N-donor ligands can show promising fluorescence properties. ${ }^{43-49}$ In this study, a novel mixed ligand Cd(II) complex with TEA and IsoPht was synthesized and the structure of the complex was identified by using X-ray single-crystal diffraction and FT-IR. Thermal properties of the complex were also examined in detail. The fluorescence and antimicrobial properties of the complex were investigated, too.

\section{Experimental}

\section{1. Materials and Instrumentations}

Triethanolamine (TEA), Isophthalic acid ( $\left.\mathrm{H}_{2} \mathrm{IsoPht}\right)$, and $\mathrm{Cd}\left(\mathrm{NO}_{3}\right)_{2} \cdot 4 \mathrm{H}_{2} \mathrm{O}$ were purchased from Sigma Aldrich Ltd. IR spectra were obtained with an FT/IR-100 type A Spectrophotometer. Thermal degradation of the complex was performed using a TA Instruments SII-EXTAR-6000 TG/DTA. Experiments were conducted from 30 to $900^{\circ} \mathrm{C}$, with a heating rate of $10^{\circ} \mathrm{C} \mathrm{min}{ }^{-1}$, under nitrogen atmosphere using platinum crucibles. Fluorescence spectra of the complex were taken on Agilent Cary Eclipse Fluorescence Spectrophotometer.

\section{2. Synthesis of [Cd(IsoPht)(TEA) $\left.\mathrm{H}_{2} \mathrm{O}\right] \cdot 3 \mathrm{H}_{2} \mathrm{O}$}

$5 \mathrm{mmol}$ of $\mathrm{Cd}\left(\mathrm{NO}_{3}\right)_{2} \cdot 4 \mathrm{H}_{2} \mathrm{O}(1540 \mathrm{mg})$ was dissolved in $30 \mathrm{~mL}$ of water. Then, $10 \mathrm{mmol}(1.33 \mathrm{~mL})$ TEA was added and reaction solution was stirred for $10 \mathrm{~min}$ at $70^{\circ} \mathrm{C}$. After that, $5 \mathrm{mmol}(830 \mathrm{mg})$ of $\mathrm{H}_{2} \mathrm{IsoPht}$ was added to the solution and stirred for more 3 hours. 4 weeks later, colorless crystals were obtained by slow evaporation of the clear solution that appeared after filtration at room temperature.

\section{3. X-Ray Crystallography}

The reflection intensities of the Cd(II) complex were collected at $296 \mathrm{~K}$ using Agilent SuperNova single-crystal diffractometer with Mo-Ka radiation $(\lambda=0.71073 \AA)$. The structure was solved using the program SHELXT ${ }^{50}$ by direct methods, and all non-hydrogen atoms were refined with anisotropic displacement parameters by full-matrix least-squares methods based on $\mathrm{F}^{2}$ using SHELXL. ${ }^{51}$ The molecular graphics were prepared using $\mathrm{OLEX}^{2}$ program. ${ }^{52}$ Detailed information about the crystal data and structure determination are summarized in Table 1. Selected experimental and calculated interatomic distances and bond angles are given in Table 2.

\section{4. Computational Protocol}

Quantum chemical calculation of the complex was performed using Gaussian 09 program suits running under Windows. ${ }^{53}$ Ground state geometry optimization of the complex was performed by using Minnesota M062X hybrid density functional method with appropriate basis set combinations, $6-31 \mathrm{~g}(\mathrm{~d}, \mathrm{p})$ for non-metal atoms and pseudo potential-included SDD for metal atom.

Table 1. Crystallographic data for $\left[\mathrm{Cd}(\mathrm{IsoPht})(\mathrm{TEA}) \mathrm{H}_{2} \mathrm{O}\right] \cdot 3 \mathrm{H}_{2} \mathrm{O}$

\begin{tabular}{|c|c|}
\hline Empirical formula & $\mathrm{C}_{14} \mathrm{H}_{27} \mathrm{CdNO}_{11}$ \\
\hline Formula weight & 497.76 \\
\hline Temperature/K & $293(2)$ \\
\hline Crystal system & Triclinic \\
\hline Space group & $P \bar{I}$ \\
\hline $\mathrm{a} / \AA$ & $9.0749(3)$ \\
\hline $\mathrm{b} / \AA$ & $10.7120(3)$ \\
\hline$c / \AA$ & $12.2025(5)$ \\
\hline$\alpha /^{\circ}$ & $66.944(3)$ \\
\hline$\beta /^{\circ}$ & $72.272(3)$ \\
\hline$\gamma /{ }^{\circ}$ & $67.510(3)$ \\
\hline Volume $/ \AA^{3}$ & $991.61(7)$ \\
\hline $\mathrm{Z}$ & 1 \\
\hline$\rho_{\text {calc }} \mathrm{g} / \mathrm{cm}^{3}$ & 1.667 \\
\hline$\mu / \mathrm{mm}^{1}$ & 1.157 \\
\hline $\mathrm{F}(000)$ & 508.0 \\
\hline Crystal size $/ \mathrm{mm}^{3}$ & $0.13 \times 0.15 \times 0.17$ \\
\hline Radiation & $\operatorname{MoKa}(\lambda=0.71073)$ \\
\hline $2 \Theta$ range for data collection $/^{\circ}$ & 6.684 to 52.742 \\
\hline Reflections collected & 13143 \\
\hline Independent reflections & $\begin{array}{l}4050\left[R_{\text {int }}=0.0400, R_{\text {sigma }}=\right. \\
0.0352]\end{array}$ \\
\hline Data/restraints/parameters & $4050 / 3 / 258$ \\
\hline $\mathrm{F}^{2}$ & 1.067 \\
\hline Final $\mathrm{R}$ indexes $[\mathrm{I}>=2 \sigma(\mathrm{I})]$ & $\mathrm{R}_{1}=0.0325, \mathrm{wR}_{2}=0.0817$ \\
\hline Final R indexes [all data] & $\mathrm{R}_{1}=0.0325, \mathrm{wR} \mathrm{R}_{2}=0.0838$ \\
\hline Largest diff. peak/hole / e $\AA^{-3}$ & $1.44 /-0.78$ \\
\hline
\end{tabular}

\section{5. Antimicrobial Activity}

In vitro antimicrobial screening test of the synthesized compound were carried out for antibacterial and antifungal activity. Antibacterial activity was tested against three bacterial strains; two gram-positive [Bacillus cereus (ATCC 10876), Staphylococcus aureus (ATCC 29213)] and one gram-negative [Escherichia coli (ATCC 25922)] and antifungal activity was tested against one fungal strain [Candida albicans (ATCC10231)]. The agar well diffusion method was used in these assays. After nutrient agar was 
sterilized in an autoclave at $121{ }^{\circ} \mathrm{C}$ for $15 \mathrm{~min}$, it was transferred into sterile Petri plates. Then the agar medium solidified, $8 \mathrm{~mm}$ diameter wells were drilled with a sterile metallic applicator. $20 \mu \mathrm{L}$ of the sample at different concentrations prepared in DMSO was poured into the wells. DMSO served as a negative control, Ampicillin and Fluconazole served as a positive control. The plates were incubated aerobically at $37^{\circ} \mathrm{C}$ for $24 \mathrm{~h}$. The diameters of inhibition zones were measured by using a zone reader and were given as millimeters. Evaluation of the inhibition zone was made by averaging the three test results.

\section{Results and Discussion}

\section{1. The Crystal Structure of [Cd(IsoPht) (TEA) $\left.\mathrm{H}_{2} \mathrm{O}\right] \cdot 3 \mathrm{H}_{2} \mathrm{O}$}

$\mathrm{X}$-ray single-crystal analysis reveals that complex crystallized in the triclinic system with space group $P \bar{I}$. The complex has an interesting monomeric molecular structure which is rarely found for cadmium polycarboxylate complexes. In the complex, $\mathrm{H}_{2}$ IsoPht acts as a bidentate ligand by losing hydrogen atoms while the TEA ligand acts as a tetradentate ligand using all its donor atoms. The Cd1 atom is coordinated by six oxygen atoms and one nitrogen atom, two of which are from IsoPht ligand (O1 and $\mathrm{O} 2$ ), three oxygen atoms, and one nitrogen atom from a TEA ligand $(\mathrm{O} 5, \mathrm{O} 6, \mathrm{O} 7$, and $\mathrm{N} 1)$, together with one oxygen atom of aqua ligand, O8W. In crystallization, uncoordinated three water molecules are also part of the molecular structure (Figure 1). Thus, Cd(II) ions are in distorted monocapped trigonal prismatic geometry environments

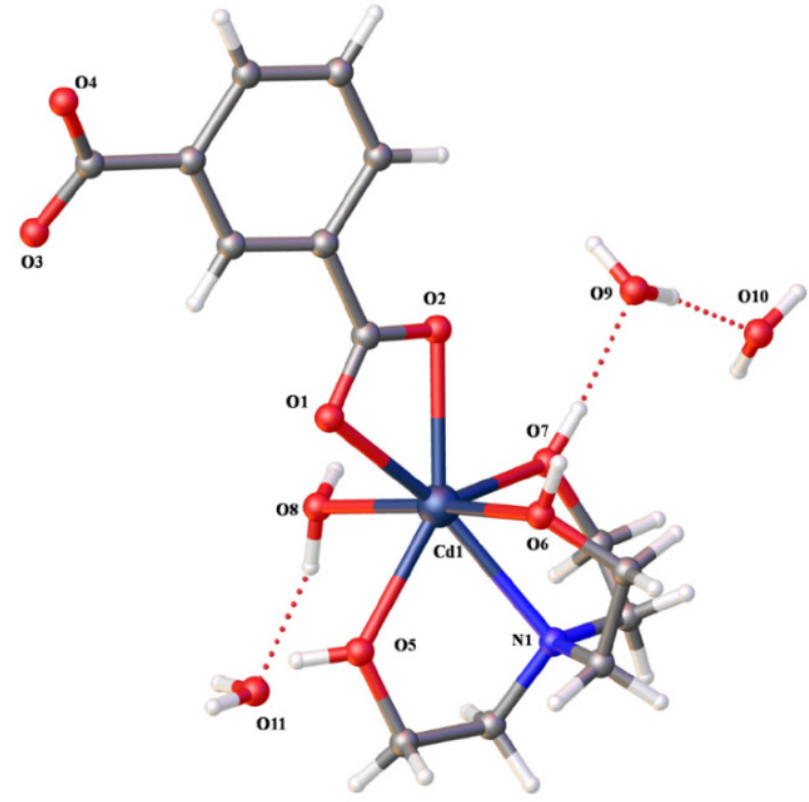

Figure 1. A view of the $\left[\mathrm{Cd}(\mathrm{IsoPht})(\mathrm{TEA}) \mathrm{H}_{2} \mathrm{O}\right] \cdot 3 \mathrm{H}_{2} \mathrm{O}$ compound showing the atom-labeling

with $\mathrm{CdO}_{6} \mathrm{~N}$ chromophores. This seven-coordinate geometry around the $\mathrm{Cd}(\mathrm{II})$ ion in the titled complex is similar to the other reported $\mathrm{Cd}(\mathrm{II})$ complexes. ${ }^{1,2}$

The Cd1-O bonds are in the range $2.300(2)-2.399$ (2) $\AA$ and Cd1-N bond is 2.434 (2) $\AA$ (Table 2). The bond lengths between $\mathrm{Cd} 1$ and $\mathrm{O}$ atoms of IsoPht $(\mathrm{O} 1, \mathrm{O} 2)$, 2.329(2) and 2.399(2) $\AA$ are comparable to the other Cd(II)-IsoPht complexes. ${ }^{46,54,55}$ The bond distances of Cd1-O and Cd1-N between Cd1 and TEA, which are in the range of $2.300(2)-2.353(2) \AA(\mathrm{O} 5, \mathrm{O} 6, \mathrm{O} 7)$ and

Table 2. Selected experimental and calculated coordination bonds and angles of [ $\left.\mathrm{Cd}(\mathrm{IsoPht})(\mathrm{TEA}) \mathrm{H}_{2} \mathrm{O}\right] \cdot 3 \mathrm{H}_{2} \mathrm{O}$

\begin{tabular}{lccccr}
\hline Bond lengths $(\AA)$ & \multicolumn{5}{c}{} \\
\hline Bond & Exp. & Calc. & Bond & Exp. & Calc. \\
Cd1-O1 & $2.329(2)$ & 2.2216 & Cd1-O6 & $2.353(2)$ & 2.5327 \\
Cd1-O2 & $2.399(2)$ & 2.2723 & Cd1-O7 & $2.325(3)$ & 2.3801 \\
Cd1-O5 & $2.300(2)$ & 2.4193 & Cd1-O8 & $2.324(2)$ & 2.4119 \\
Cd1-N1 & $2.434(2)$ & 2.4485 & & & \\
\hline Bond angles $\left(^{\circ}\right)$ & & & & & Exp. \\
\hline Angle & Exp. & Calc. & Angle & $131.11(10)$ & 126.59 \\
\hline O1-Cd1-O2 & $55.12(7)$ & 58.86 & O5-Cd1-O7 & 103.19 \\
O1-Cd1-O6 & $86.17(9)$ & 92.92 & O7-Cd1-O2 & $80.08(8)$ & 132.58 \\
O8-Cd1-O2 & $94.06(8)$ & 131.99 & O7-Cd1-O1 & $134.14(8)$ & 123.19 \\
O8-Cd1-O1 & $88.16(9)$ & 87.74 & O7-Cd1-O6 & $103.78(11)$ & 152.40 \\
O8-Cd1-O6 & $170.64(9)$ & 152.86 & O1-Cd1-N1 & $150.55(8)$ & 127.47 \\
O8-Cd1-O7 & $85.50(11)$ & 73.38 & O2-Cd1-N1 & $140.73(7)$ & 74.03 \\
O6-Cd1-O2 & $88.80(8)$ & 69.16 & O5-Cd1-N1 & $70.83(8)$ & 69.51 \\
O5-Cd1-O2 & $146.41(8)$ & 130.20 & O6-Cd1-N1 & $72,15(8)$ & 74.64 \\
O5-Cd1-O1 & $91.61(8)$ & 83.14 & O7-Cd1-N1 & $72.00(8)$ & 98.47 \\
O5-Cd1-O8 & $78.85(9)$ & 69.84 & O8-Cd1-N1 & $110.61(8)$ & \\
O5-Cd1-O6 & $93.86(10)$ & 83.29 & & & \\
\hline
\end{tabular}


2.434(2) $\AA$ (N1), are similar within the reported seven-coordinated mixed ligand complexes. ${ }^{16,23}$ However, these bond lengths are shorter than those of the reported eight-coordinated complexes. ${ }^{3,22}$ In addition, the bond angles between the $\mathrm{Cd} 1$ and $\mathrm{O}$ atoms vary between $55.12^{\circ}(7)$ and $170.64^{\circ}(9)$ in Table 2. The bond angles of the complex are normal compared with those of the related complexes. ${ }^{1,2,16}$ The crystal structure is further stabilized by multiply intermolecular hydrogen bonds. The uncoordinated water molecules play an important role in the supramolecular architecture. The hydrogen-bonding interactions, which are assembled into $2 \mathrm{D}$ layers parallel to by $\mathrm{O}-\mathrm{H}$... O weak hydrogen bonds (Table 3), formed where the TEA donate hydrogen atoms to the neighboring carboxylate and water oxygens (Figure 2). It can be seen from Figure 2 that the hydrogen bonds between the TEA ligands and the car-

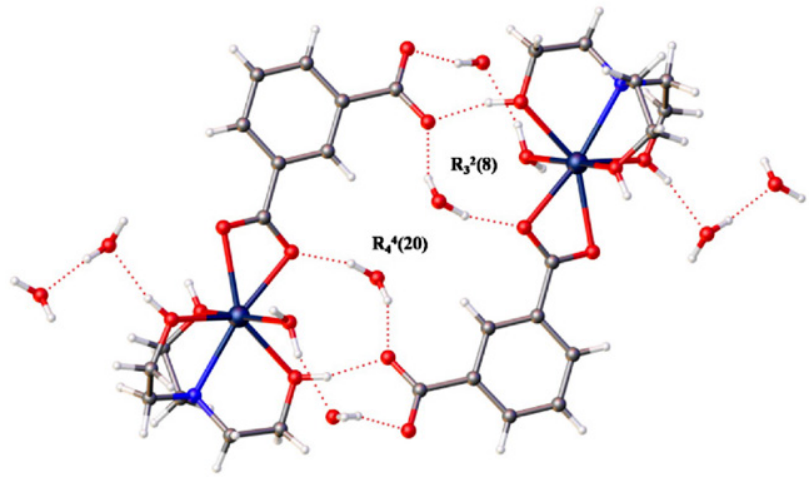

Figure 2. Part of the crystal structure of [Cd(IsoPht)(TEA) $\left.\mathrm{H}_{2} \mathrm{O}\right] \cdot 3 \mathrm{H}_{2} \mathrm{O}$, showing the formation of $\mathrm{R}_{3}^{2}(8)$, and $\mathrm{R}_{4}{ }^{4}(20)$ rings by the $\mathrm{O}-\mathrm{H}$-..O hydrogen bonds

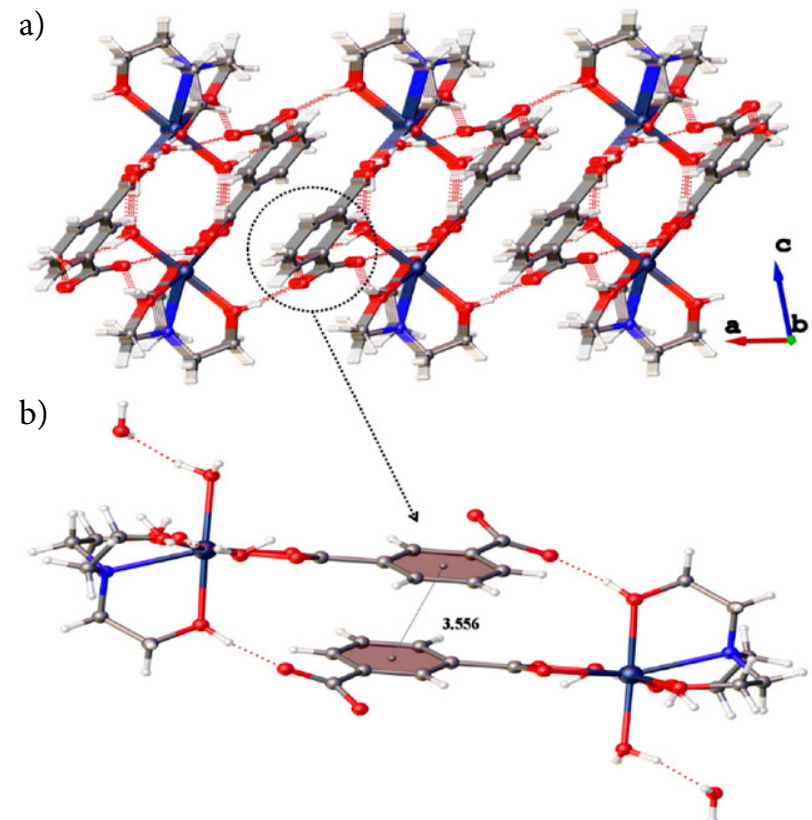

Figure 3. ((a) 2-D supramolecular network along the [010] direction in $\left[\mathrm{Cd}(\mathrm{IsoPht})(\mathrm{TEA}) \mathrm{H}_{2} \mathrm{O}\right] \cdot 3 \mathrm{H}_{2} \mathrm{O}$ complex. (b) $\pi \cdots \pi$ interaction boxylate groups of IsoPht, giving rise to $\mathrm{R}_{3}{ }^{2}(8)$ and $\mathrm{R}_{4}{ }^{4}(20)$ ring motives. The molecules located along the [010] direction (Figure $3(\mathrm{a})$ ), are linked by $\pi \cdots \pi$ stacking $[\pi \cdots \pi \mathrm{d}=$ $3.556 \AA]$ (Figure 3(b)). The $\pi \cdots \pi$ stacking interaction between the benzene ring of the IsoPht ligand is stronger than in the related $\left\{\left[\mathrm{Cd}(\mathrm{HFlu})(\mathrm{IsoPht})\left(\mathrm{H}_{2} \mathrm{O}\right)\right] \cdot \mathrm{H}_{2} \mathrm{O}\right\} \mathrm{n}(\mathrm{HFlu}=$ fluconazole) complex $[\pi \cdots \pi \mathrm{d}=3.705 \AA]$ in literature. ${ }^{46}$

An extensive network of hydrogen bonds, $\pi \cdots \pi$ stacking, and van der Walls interactions embed the complex in a three-dimensional lattice. Figure 4 shows the packing diagram of the complex along the [100] direction.

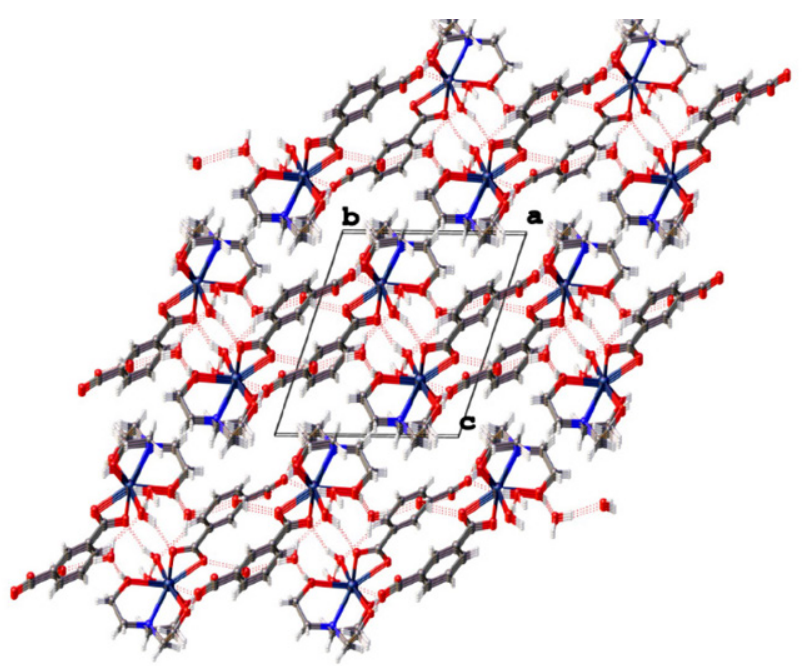

Figure 4. Packing diagram of $\left[\mathrm{Cd}(\mathrm{IsoPht})(\mathrm{TEA}) \mathrm{H}_{2} \mathrm{O}\right] \cdot 3 \mathrm{H}_{2} \mathrm{O}$ complex along the [100] direction

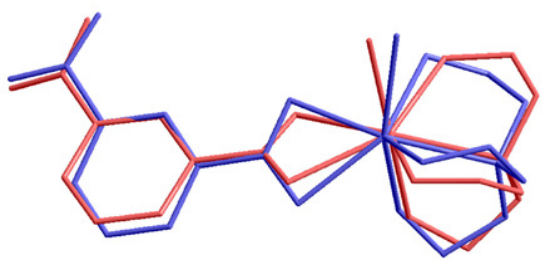

Figure 5. Superimposition of $\mathrm{X}$-ray(red) and optimized(blue) geometries of $\left[\mathrm{Cd}(\mathrm{IsoPht})(\mathrm{TEA}) \mathrm{H}_{2} \mathrm{O}\right] \cdot 3 \mathrm{H}_{2} \mathrm{O}$

Table 3. Hydrogen bond interactions for [Cd(IsoPht)(TEA) $\left.\mathrm{H}_{2} \mathrm{O}\right] \cdot 3 \mathrm{H}_{2} \mathrm{O}$

\begin{tabular}{|c|c|c|c|c|}
\hline \multicolumn{5}{|c|}{ Hydrogen-bonds } \\
\hline $\mathrm{D}-\mathrm{H} \cdots \mathrm{A}$ & $\mathrm{D}-\mathrm{H}$ & $\mathrm{H} \cdots \mathrm{A}$ & $\mathrm{D} \cdots \mathrm{A}$ & $\mathrm{D}-\mathrm{H} \cdots \mathrm{A}$ \\
\hline O8-H8-O9i & 0.85 & $2.08(4)$ & $2.895(4)$ & 161.9 \\
\hline O8-H8-O11 & 0.85 & 1.98 & $2.818(4)$ & 167.2 \\
\hline O6-H6-O4 ${ }^{\mathrm{ii}}$ & $0.89(5)$ & $1.71(5)$ & $2.598(3)$ & $176(5)$ \\
\hline $\mathrm{O} 5-\mathrm{H} 5-\mathrm{O} 3^{\mathrm{iii}}$ & $0.73(5)$ & $1.81(5)$ & $2.536(4)$ & $169(6)$ \\
\hline O9-H9-O10 & 0.85 & 1.84 & $2.693(4)$ & 176.2 \\
\hline O9-H9-O8 ${ }^{\mathrm{i}}$ & 0.85 & 2.26 & $2.895(4)$ & 132.0 \\
\hline $\mathrm{O} 10-\mathrm{H} 10-\mathrm{O} 1^{\mathrm{iv}}$ & 0.85 & 2.01 & $2.808(3)$ & 156.1 \\
\hline $\mathrm{O} 10-\mathrm{H} 10-\mathrm{O} 3^{\mathrm{i}}$ & 0.85 & 1.91 & $2.743(4)$ & 165.0 \\
\hline $\mathrm{O} 11-\mathrm{H} 11-\mathrm{O} 4^{\mathrm{iii}}$ & 0.85 & 2.11 & $2.928(4)$ & 162.5 \\
\hline
\end{tabular}

Symmetry transformations used to generate equivalent atoms: (i) $x$, 1-y, 1-z; (ii) x, 2-y, 1-z; (iii) 1-x, 2-y, 1-z; (iv) $+\mathrm{z},-1+\mathrm{y},+\mathrm{z}$ 
Quantum chemical optimized geometry of the complex exhibited reasonable accordance with experimental X-ray geometry with a RMSE deviation of $0.622 \AA$ A Superimpositions of the X-ray and calculated geometries of the complex are given in Figure 5. In general, there is a pleasant consistence between optimized and X-ray geometries according to the results and as expected, the general tendency of gas-phase optimizations in favour of somewhat extending the bond distances was introduced.

\section{2. FT-IR Study}

In the FT-IR spectrum of the Cd(II) complex, the broad absorption band between 3500 and $3100 \mathrm{~cm}^{-1}$ with maxima at 3427,3385 and $3146 \mathrm{~cm}^{-1}$, which are assigned to stretching vibrations $v(\mathrm{O}-\mathrm{H})$ of uncoordinated water molecules, aqua and TEA ligand (Figure S1). The FT-IR stretching band at $3373 \mathrm{~cm}^{-1}$ belongs to the hydroxyl group $(\mathrm{O}-\mathrm{H})$ of the TEA ligand and has been observed to shift to lower wavelength $\left(3146 \mathrm{~cm}^{-1}\right)$ during complexation. The FT-IR bands identified at 3079, 2975, 2898 and $2844 \mathrm{~cm}^{-1}$ are associated with aromatic and aliphatic $v(\mathrm{C}-\mathrm{H})$ stretching vibrations. The bands in the spectral region $1700-1300 \mathrm{~cm}^{-1}$ of complex shows five peaks with frequencies 1601, 1538, 1479, 1442 and $1390 \mathrm{~cm}^{-1}$. These bands can be attributed to stretching vibrations of aromatic ring $v\left(\mathrm{C}_{\mathrm{Ar}}\right)$ and carboxylate groups $v(\mathrm{C}=\mathrm{O})$. The peaks corresponding to a strong asymmetric stretching $v_{\text {asym }}(\mathrm{C}=\mathrm{O})$ as $1689 \mathrm{~cm}^{-1}$ and a weak symmetric stretching $v_{\text {sym }}(\mathrm{C}=\mathrm{O})$ as $1417 \mathrm{~cm}^{-1}$ of the $\mathrm{H}_{2}$ IsoPht were observed at lower frequencies $\left(1538 \mathrm{~cm}^{-1}\right.$ and $1390 \mathrm{~cm}^{-1}$, respectively). This situation demonstrates that the Isopht ligand coordinated to the $\mathrm{Cd}(\mathrm{II})$ via the oxygen atoms of the car- boxylate group. The difference between the $v_{\text {asym }}(\mathrm{C}=\mathrm{O})$ and $v_{\text {sym }}(\mathrm{C}=\mathrm{O})$ stretching vibrations observed in the IR spectra of the complexes $(\Delta v),\left[\Delta v=v_{\text {asym }}(C=O)-\right.$ $\left.v_{\text {sym }}(\mathrm{C}=\mathrm{O})\right]$ is used to determine the coordination type of the carboxylate group. The frequency difference, $\Delta v>200$ $\mathrm{cm}^{-1}$ generally associated with unidentate coordination, a possible exception involving highly unsymmetrical bridging, i.e. "pseudo-unidentate" coordination. $\Delta v>105 \mathrm{~cm}^{-1}$ and $<200 \mathrm{~cm}^{-1}$ indicates chelating and/or bridging carboxylate groups. Accordingly, the value of $\Delta v 148 \mathrm{~cm}^{-1}$ for the complex indicated that the chelate coordination mode of the carboxyl group of the IsoPht. ${ }^{56,57}$ The coordination mode of IsoPht ligand is also approved by the single-crystal X-ray structure examined. The band observed at 434 $\mathrm{cm}^{-1}$ is due to the metal-oxygen $(\mathrm{M}-\mathrm{O})$ bond. ${ }^{58}$

\section{3. Thermal Analysis}

Thermal stability and behavior of the Cd(II) complex were examined by simultaneous TG/DTG/DTA in nitrogen atmosphere. The TG-DTG and DTA curves of the complex are shown in Figure 6. The complex underwent complete degradation in two main stages. The first stage $\left(44-118^{\circ} \mathrm{C}\right)$, is related to the removal of both crystal water and aqua ligand at $\mathrm{DTG}_{\max } 88^{\circ} \mathrm{C}$ with a $13.98 \%$ mass loss. This exhibits an endothermic peak at $89^{\circ} \mathrm{C}$ in the DTA curve. The anhydrous complex stays stable up to $179^{\circ} \mathrm{C}$. Over this temperature, it can be suggested that the TEA and IsoPht ligands removed successively from the structure in the temperature range of $179-657^{\circ} \mathrm{C}\left(\mathrm{DTG}_{\max }\right.$ : $378^{\circ} \mathrm{C}$ ). The final solid product of thermal decomposition is associated with $\mathrm{CdO}$ formation (found 27.7, calcd. $25.8 \%)$.

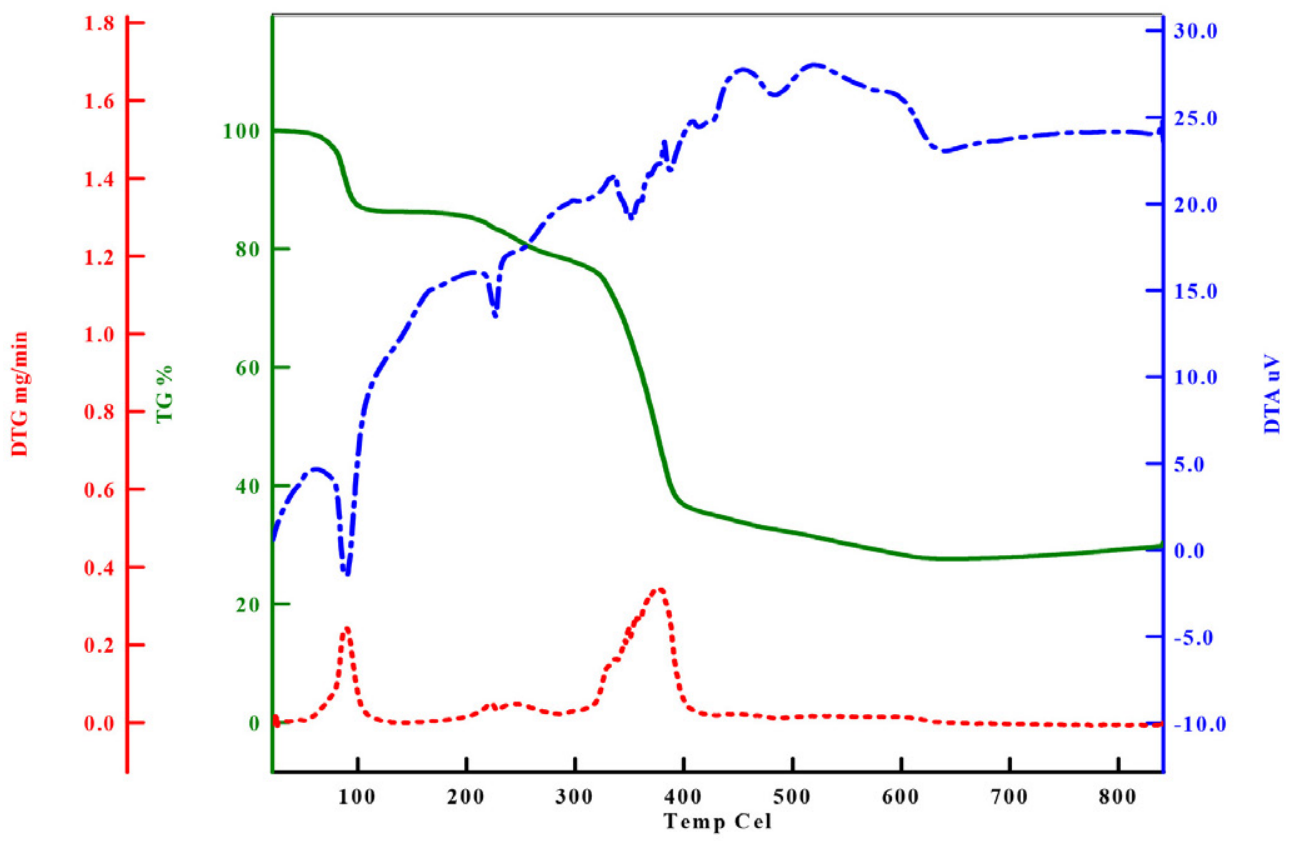

Figure 6. TGA curves of $\left[\mathrm{Cd}(\mathrm{IsoPht})(\mathrm{TEA}) \mathrm{H}_{2} \mathrm{O}\right] \cdot 3 \mathrm{H}_{2} \mathrm{O}$ complex 


\section{4. Fluorescence Properties}

The fluorescent properties of the TEA ligand and Cd(II) complex have been examined at room temperature. The resulting emission spectrum is given in Figure 7. Due to the fluorescence quenching of carboxyl groups of IsoPht (which are strong electron-attracting groups), this ligand shows very low fluorescence emission at room temperature. ${ }^{48,59}$ While the TEA ligand shows the emission peaks at 312 and $346 \mathrm{~nm}$ with the excitation at $270 \mathrm{~nm}$, the complex exhibits emission bands at 357 and $423 \mathrm{~nm}$ with the excitation at $270 \mathrm{~nm}$. Compared with the emission of the TEA ligand, the emission peaks of the complex were observed to redshift (ca.45 $\mathrm{nm}$ and $77 \mathrm{~nm}$ ). The solid-state fluorescence of the complex may be assigned to MLCT or LMCT transitions. ${ }^{60}$

\section{5. Antimicrobial Activity}

The antimicrobial activity of the prepared [Cd(IsoPht)(TEA) $\left.\mathrm{H}_{2} \mathrm{O}\right] \cdot 3 \mathrm{H}_{2} \mathrm{O}$ complex against three bac- teria and one fungus was studied. Saturated solution and inhibition zones $(\mathrm{mm})$ of the $\mathrm{Cd}(\mathrm{II})$ complex are given in Table 4. In the different concentrations of the complex, various inhibition values were observed for $B$. cereus, $S$. aureus, E. coli, and C. albicans between $10-25 \mathrm{~mm}, 7-20$ $\mathrm{mm}, 16-18 \mathrm{~mm}$, and $8-15 \mathrm{~mm}$ respectively. It was shown more efficacy than positive control against all three bacterial zones, especially at concentrations of 40000 and 20000 ppm.

Recently, it has been reported that $\mathrm{Cu}(\mathrm{II})$ complexes of TEA with salts of salicylic, cinnamic, and succinic acids, ${ }^{6} \mathrm{Zn}(\mathrm{II})$ and $\mathrm{Cu}(\mathrm{II})$ cinnamate with TEA complexes ${ }^{61}$ showed antimicrobial activity against bacteria E. coli, S. aureus, $M$. smegmatis, fungi $C$. albicans and $A$. niger. In addition, it has been shown that TEA with $\mathrm{Cu}(\mathrm{II})$ picrate and $\mathrm{Ag}(\mathrm{I})$ complexes appeared to exhibit mild to moderate activity towards $S$. marcescens, $S$. japonicum, $S$. maltophilia and $S$. aureus. ${ }^{62,10}$ Compared to these previous studies, it can be said that the Cd(II) complex synthesized in this study has a moderate inhibitory activity against similar strains.

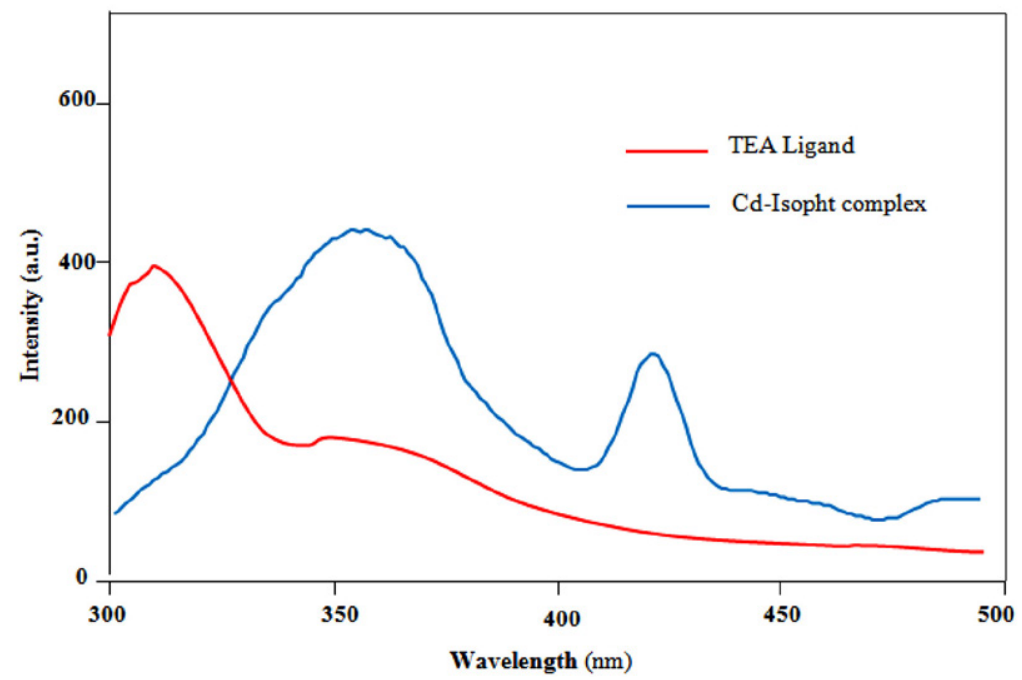

Figure 7. Fluorescence spectrum of $\left[\mathrm{Cd}(\mathrm{IsoPht})(\mathrm{TEA}) \mathrm{H}_{2} \mathrm{O}\right] \cdot 3 \mathrm{H}_{2} \mathrm{O}$ complex and TEA ligand in the solid-state $\left(\lambda_{\mathrm{ex}}=270 \mathrm{~nm}\right)$

Table 4. Diameter of zones of inhibition ( $\mathrm{mm})$ of $\left[\mathrm{Cd}(\mathrm{IsoPht})(\mathrm{TEA}) \mathrm{H}_{2} \mathrm{O}\right] \cdot 3 \mathrm{H}_{2} \mathrm{O}$ complex

\begin{tabular}{lcccc}
\hline ppm & S.aureus & B.cereus & E.coli & C.albicans \\
\hline 40000 & 20 & 25 & 18 & 15 \\
20000 & 20 & 25 & 16 & 15 \\
10000 & 15 & 20 & 0 & 12 \\
5000 & 13 & 16 & 0 & 8 \\
2500 & 9 & 15 & 0 & 0 \\
1250 & 7 & 15 & 0 & 0 \\
625 & 0 & 14 & 0 & 0 \\
312.5 & 0 & 10 & 0 & 0 \\
${ }^{a} D M S O$ & - & - & - & - \\
${ }^{b}$ Ampicilin $(10 \mu \mathrm{g} / \mathrm{mL})$ & 18 & 20 & 15 & - \\
bFlukonozol $(25 \mu \mathrm{g} / \mathrm{mL})$ & - & - & - & 20 \\
\hline
\end{tabular}

a: negative control; b: positive control 
The antimicrobial activity of mixed ligand metal complex was determined by various factors such as the chelate effect, i.e. bidentate, tridentate or tetradentate ligands, the nature of ligand, the total charge of the complex, and metal ion located in the center. ${ }^{63}$ In light of this information, it can be said that despite the weak antimicrobial activity of TEA alone, ${ }^{8,9}$ the complex formed by combining with $\mathrm{Cd}$ (II) ion shows moderate antimicrobial activity against all tested strains.

\section{Conclusions}

A novel mixed ligand $\left[\mathrm{Cd}(\mathrm{IsoPht})(\mathrm{TEA}) \mathrm{H}_{2} \mathrm{O}\right] \cdot 3 \mathrm{H}_{2} \mathrm{O}$ complex was synthesized and structurally characterized. The revealed X-ray structure clearly showed that the complex has a distorted monocapped trigonal prismatic geometry by binding to $\mathrm{Cd}(\mathrm{II})$ ion as TEA tetradentate and IsoPht bidentate. Thermal stability and behavior of the complex in the nitrogen atmosphere were investigated. The complex was completely degraded in two main stages. Fluorescence properties of cadmium complex having $\mathrm{d}^{10}$ electron configuration at room temperature were also measured. In the fluorescence spectrum, the red-shift of the peaks of the complex may be attributed to the LMCT or MLCT transitions. In addition, the antimicrobial properties of the complex were investigated against three bacteria and one fungus. Data on the antimicrobial activity of the Cd(II) chelate complex formed by the tetradentate TEA and bidentate IsoPht ligands shows supported that it demonstrated moderate activity to inhibit the growth of all tested strains.

\section{Supplementary Data}

Crystallographic data have been deposited with the Cambridge Crystallographic Data Centre as supplementary publication No. CCDC 1977619. Copies of the data can be obtained, free of charge, on application to CCDC, 12 Union Road, Cambridge CB2 1EZ, UK (fax: +44-1223336033 or e-mail: deposit@ccdc.cam.ac.uk).

\section{Acknowledgments}

The authors would like to thank Dr. Esra Deniz Candan for the assistance of antimicrobial activity determination, and Assoc. Prof. Dr. Serkan Demir for his helpful advice on theoretical calculations.

\section{References}

1. O. Andac, Y. Topcu, V. T. Yilmaz, K. Guven, Acta Cryst. 2001, C57, 1381-1384. DOI:10.1107/S0108270101015049

2. I. Ucar, O. Z. Yesilel, A. Bulut, H. Icbudak, H. Ölmez, C. Kazak, Acta Cryst. 2004, C60, 392-394.

DOI:10.1107/S0108270104013174
3. J. M. Ashurov, Acta Cryst. 2016, E72, 526-529. DOI:10.1107/S2056989016004515

4. M. Rubab, M. N. Akhtar, W. Zierkiewicz, M. Michalczyk, R. Nadeem, M. Shahid, M. N. Tahir, M. Akram, M. A. Hanif, M. A. AlDamen, Res. Chem. Intermed. 2019, 45, 5649-5664. DOI:10.1007/s11164-019-03927-9

5. Z. Boulsourani, G. D. Geromichalos, K. Repana, E. Yiannaki, V. Psycharis, C. P. Raptopoulou, D. Hadjipavlou-Litina, E. Pontiki, C. Dendrinou-Samara, J. Inorg. Biochem. 2011, 105, 839-849. DOI:10.1016/j.jinorgbio.2011.03.007

6. Y. Kondratenko, A. A. Zolotarev, I. Ignatyev, V. Ugolkov, T. Kochina, Transit. Met. Chem. 2020, 45, 71-81. DOI:10.1007/s11243-019-00359-7

7. T. Esker, A. DeBoo, Y. Ishiwa, Ethanolamines. CEH Report, SRI Consulting, California, USA, 1999.

8. K. H. Beyer, W. F. Bergfeld, W. O. Berndt, R. K. Boutwell, W. W. Carlton, D. K. Hoffmann, A. L. Schroeder, J. Am. Coll. Toxicol. 1983, 2, 183-235.

9. J. B. Knaak, H. W. Leung, W. T. Stott, J. Busch, J. Bilsky, Rev. Environ. Contam. Toxicol. 1997, 149, 1-86. DOI:10.1007/978-1-4612-2272-9_1

10. R. Kumar, S. Obrai, A. Kaur, M. S. Hundal, H. Meehnian, A. K. Jana, New J Chem. 2014, 38, 1186-1198. DOI:10.1039/c3nj00729d

11. G. M. Kapteijn, P. J. Baesjou, P. L. Alsters, D. M. Grove, W. J. J. Smeets, H. Kooijman, A. L. Spek, G. Koten, Chem. Ber. 1997, 130, 34-44. DOI:10.1002/cber.19971300106

12. I. Ignatyev, Y. Kondratenko, V. Fundamensky, T. Kochina, Transit. Met. Chem. 2018, 43, 127-136.

DOI:10.1007/s11243-017-0199-8

13. A. C. Dumitriu, M. Cazacu, A. Bargan, S. Shova, C. Turta, Polyhedron, 2013, 50, 255-263. DOI:10.1016/j.poly.2012.11.009

14. O. Z. Yesilel, H. Ölmez, I. Ucar, A. Bulut, C. Kazak, Z. Anorg. Allg. Chem. 2005, 631, 3100-3103.

DOI:10.1002/zaac.200500297

15. V. T. Yilmaz, E. Senel, Transit. Met. Chem. 2004, 29, 336-342. DOI:10.1023/B:TMCH.0000020381.99658.ac

16. J. M. Ashurov, A. B. Ibragimov, B. T. Ibragimov, Polyhedron, 2015, 102, 441-446. DOI:10.1016/j.poly.2015.05.044

17. Y. Kondratenko, V. Fundamenskya, I. Ignatyev, A. Zolotarev, T. Kochina, V. Ugolkova, Polyhedron, 2017, 130, 176-183. DOI:10.1016/j.poly.2017.04.022

18. S. Gao, J. W. Liu, J. R. Li, L. H. Huo, H. Zhao, Acta Cryst. 2004, E60, m94-m95. DOI:10.1107/S1600536803028630

19. H. Guo, S. K. Huang, X. Z. Li, Acta Cryst. 2009, E65, m891. DOI:10.1107/S1600536809026166

20. M. Haukka, A. M. Kirillov, M. N. Kopylovich, A. J. L. Pombeiro, Acta Cryst. 2005, E61, m2746-m2748.

DOI:10.1107/S1600536805039127

21. Y. P. Li, H. Zang, D. Sun, J. Ming, G. F. Sua, Acta Cryst. 2014, E70, m361-m362. DOI:10.1107/S1600536814021771

22. Y. P. Li, L. Y. Han, J. Ming, G. F. Su, Acta Cryst. 2014, E70, m371. DOI:10.1107/S1600536814022375

23. X. He, J. Lv, G. Xu, Acta Cryst. 2012, C68, m109-m112.

24. A. Dicko, P. Tardi, X. Xie, L. Mayer, Int. J. Pharm. 2007, 337, 219-228. 
25. M. G. Voronkov, G. A. Kuznetsova, A. Y. Fedorin, G. G. Yshkov, A. V. Mashanov, N. A. Malishkina, M. M. Rasulov, Pat. RF. No 2418580, 2009.

26. M. G. Voronkov, A. Y. Fedorin, V. Mashanov, N. A. Malishkina, G. A. Kuznetsova, G. G. Yshkov, Pat. RF. No 2425676, 2010.

27. O. P. Kolesnikova, A. N. Mirskova, S. N. Adamovich, R. G. Mirskov, O. T. Kudaeva, M. G. Voronkov, Dokl. Biol. Sci. 2009, 425, 556-560. DOI:10.1134/S0012496609020070

28. M. M. Rasulov, M. G. Voronkov, M. K. Nurbekov, M. V. Zvereva, A. N. Mirskova, S. N. Adamovich, R. G. Mirskov, Dokl. Biochem. Biophys. 2012, 444, 147-148.

DOI:10.1134/S1607672912030064

29. T. Hambley, Science. 2007, 318, 1392-1393. DOI:10.1126/science.1150504

30. T. Storr, K. H. Thompson, C. Orvig, Chem. Soc. Rev. 2006, 35, 534-544. DOI:10.1039/b514859f

31. S. Zhan, Y. Sun, S. Li, G. Tang, Y. Wang, Y. Cui, Polyhedron, 2017, 121, 252-263. DOI:10.1016/j.poly.2016.10.016

32. X. Shi, P. Chen, Z. Yin, T. Li, M. Wu, L. Tian, Polyhedron, 2018, 141,87-93. DOI:10.1016/j.poly.2017.11.019

33. S. L. Cai, L. Lu, W. P. Wu, J. Wang, Y. C. Sua, A. Q. Ma, A. Singh, A. Kumar, Inorg. Chim. Acta, 2019, 484, 291-296.

DOI:10.1016/j.ica.2018.09.066

34. M. Antonijević Nikolić, J. Antić-Stanković, B. Dražićc, S. Tanasković, J. Mol. Struct. 2019, 1184, 41-48. DOI:10.1016/j.molstruc.2018.10.027

35. Z. Lin, J. Luo, M. Hong, R. Wang, L. Han, R. Cao, J. Solid State Chem. 2004, 177, 2794-2498.

DOI:10.1016/j.jssc.2004.04.005

36. Y. Wang, L. Wang, X. Zhou, Y. Li, J. Li, J. Mol. Struct. 2018, 1173, 612-619. DOI:10.1016/j.molstruc.2018.07.025

37. J. Ge, J. Cheng, P. Wang, Q. Liu, Y. Dong, J. Mol. Struct. 2014, 1056-1057, 127-134. DOI:10.1016/j.molstruc.2013.10.029

38. W. Song, X. Cui, X. Wang, L. Liang, E. Yang, X. Zhao, Polyhedron, 2017, 127, 266-277. DOI:10.1016/j.poly.2017.02.012

39. L. Radovanović, J. Rogan, D. Poleti, M. Milutinović, M. V. Rodić, Polyhedron, 2016, 112, 18-26.

DOI:10.1016/j.poly.2016.03.054

40. M. Devereux, M. McCann, V. Leon, M. Geraghty, V. McKee, J. Wikaira, Met. Based Drugs, 2000, 7, 275-288.

41. M. Geraghty, V. Sheridan, M. McCann, M. Devereux, V. McKee, Polyhedron, 1999, 18, 2931-2939.

DOI:10.1016/S0277-5387(99)00201-6

42. P. K. Panchal, M. N. Patel, Synth. React. Inorg. Met. Org. Chem. 2004, 34, 1277-1289.

DOI:10.1081/SIM-120039271

43. K. Yue, S. Zhao, R. Zhao, Y. Wang, Adv. Mater. Res. 2012, 399401, 896-899.

DOI:10.4028/www.scientific.net/AMR.399-401.896

44. X. C. Cheng, X. H. Zhu, H. W. Kuai, Z. Naturforsch, B J. Chem. Sci. 2013, 68, 1000-1006.

DOI:10.5560/znb.2013-3165

45. H. W. Kuai, X. Y. Xu, X. C. Cheng, L. D. Feng, X. H. Zhu, J. Coord. Chem. 2013, 66, 4304-4315.

DOI:10.1080/00958972.2013.867025
46. G. Pan, J. Tang, X. Yin, W. Tian, Z. Huang, Z. Naturforsch B: J. Chem. Sci. 2013, 68, 1333-1339.

DOI:10.5560/znb.2013-3185

47. L. Liu, S. Zhang, Y. Wang, X. Guo, L. Wu, B. Wu, Inorg. Chim. Acta 2014, 423,176-183.

DOI:10.1016/j.ica.2014.08.010

48. H. Lin, F. Sui, P. Liu, X. Wang, G. Lin, Bull. Korean Chem. Soc. 2013, 34, 2138-2142. DOI:10.5012/bkcs.2013.34.7.2138

49. X. Yi, W. Chen, J. Huang, D. Zhang, Y. Wang, Acta Chim Slov. 2017, 64, 1042-1047.

50. G. M. Sheldrick, Acta Cryst. 2015, A71, 3-8. DOI: $10.1107 /$ S2053229614024218

51. G. M. Sheldrick, Acta Cryst. 2015, C71, 3-8. DOI:10.1107/S2053229614024218

52. O. Dolomanov, L. Bourhis, R. Gildea, J. Howard, H. Puschmann, J. Appl. Crystallogr. 2009, 42, 339-341. DOI:10.1107/S0021889808042726

53. M. J. Frisch, G. W. Trucks, H. B. Schlegel, G. E. Scuseria, M. A. Robb, J. R. Cheeseman, G. Scalmani, V. Barone, B. Mennucci, G. A. Petersson, H. Nakatsuji, M. Caricato, X. Li, H. P. Hratchian, A. F. Izmaylov, J. Bloino, G. Zheng, J. L. Sonnenberg, M. Hada, M. Ehara, K. Toyota, R. Fukuda, J. Hasegawa, M. Ishida, T. Nakajima, Y. Honda, O. Kitao, H. Nakai, T. Vreven, J. A. Montgomery, Jr., J. E. Peralta, F. Ogliaro, M. Bearpark, J. J. Heyd, E. Brothers, K. N. Kudin, V. N. Staroverov, R. Kobayashi, J. Normand, K. Raghavachari, A. Rendell, J. C. Burant, S. S. Iyengar, J. Tomasi, M. Cossi, N. Rega, J. M. Millam, M. Klene, J. E. Knox, J. B. Cross, V. Bakken, C. Adamo, J. Jaramillo, R. Gomperts, R. E. Stratmann, O. Yazyev, A. J. Austin, R. Cammi, C. Pomelli, J. W. Ochterski, R. L. Martin, K. Morokuma, V. G. Zakrzewski, G. A. Voth, P. Salvador, J. J. Dannenberg, S. Dapprich, A. D. Daniels, Ö. Farkas, J. B. Foresman, J. V. Ortiz, J. Cioslowski, D. J. Fox, Gaussian 09, Revision A.1, Gaussian, Inc., Wallingford CT, 2009.

54. J. Tao, X. M. Chen, R. B. Huang, L. S. Zheng, J. Solid State Chem. 2003, 170, 130-134.

55. L. Tian, L. Yan, S. Y. Liu, J. Coord. Chem., 2011, 64, 16, $2945-$ 2952. DOI:10.1080/00958972.2011.609594

56. G. B. Deacon, R. J. Phillips, Coord. Chem. Rev. 1980, 33, $227-$ 250. DOI:10.1016/S0010-8545(00)80455-5

57. K. Nakamoto, Handbook of Vibrational Spectroscopy. 2006, pp. 1872-1892.

58. K. Anandhan, R. Thilak Kumar, Spectrochim. Acta, Part A. 2015, 149, 476-480. DOI:10.1016/j.saa.2015.04.035

59. X. Shi, G. Zhu, Q. Fang, G. Wu, G. Tian, R. Wang, D. Zhang, M. Xue, S. Qiu, Eur. J. Inorg. Chem. 2004, 1, 185-191. DOI:10.1002/ejic.200300390

60. G. Sun, H. Huang, X. Tian, Y. Song, Y. Zhu, Z. Yuan, W. Xu, M. Luo, S. Liu, X. Feng, F. Luo, Cryst. Eng. Comm. 2012, 14, 6182-6189. DOI:10.1039/c2ce25602a

61. Y. A. Kondratenko, V. L. Ugolkov, D. Y. Vlasov, T. A. Kochina, Mendeleev Commun., 2020, 30, 639-641.

DOI:10.1016/j.mencom.2020.09.029

62. R. Kumar, S. Obrai, A. Kaur, G. Hundal, H. Meehnian, A.K. Jana, Polyhedron, 2013, 56, 55-61.

DOI:10.1016/j.poly.2013.03.043 
63. M. Rizzotto, Metal Complexes as Antimicrobial Agents. In: Bobbarala V (ed) A Search for Antibacterial Agents, IntechOpen, Rijeka, 2012, pp. 73-86. DOI:10.5772/45651

\section{Povzetek}

$\mathrm{Z}$ uporabo izoftalne kisline $\left(\mathrm{H}_{2} \mathrm{IsoPht}\right)$ in tetradentatnega trietanolamina (TEA) smo sintetizirali nov kadmijev(II) kompleks s formulo [Cd(IsoPht)(TEA) $\left.\mathrm{H}_{2} \mathrm{O}\right] \cdot 3 \mathrm{H}_{2} \mathrm{O}$ in dobljeno spojino karakterizirali z monokristalno rentgensko difrakcijo, FT-IR in termogravimetrično analizo (TGA). Spojina kristalizira triklinsko v prostorski skupini $P-1$ s popačeno trikotno prizmo z dodatnim ligandom nad stransko ploskvijo. Cd(II) je sedemštevno koordiniran z bidentatnim IsoPht, tetradentatnim TEA in akva ligandom. Preučevali smo fluorescenčne lastnosti kadmijevega kompleksa in liganda TEA. Raziskovali smo tudi antimikrobno aktivnost sintetiziranega Cd(II) kompleksa $\mathrm{z}$ in vitro metodo difuzije $\mathrm{v}$ agarju proti gram pozitivnim in gram negativnim bakterijam ter glivam. 